\title{
The Knowledge Enablers of Knowledge Transfer: A Study in the Construction Industries in Ghana
}

\begin{abstract}
Purpose - This research investigates and identifies knowledge transfer (KT) enablers within the developing country of Ghana. These enablers act as mechanisms to stimulate knowledge creation, knowledge protection and build effective knowledge sharing (KS) behavior in construction companies - consequently, they are crucial to business survival in a globally competitive market.

Design/ methodology/ approach - A perceptional questionnaire survey was used to elicit responses from construction practitioners using purposive and snowballing non-probability sampling techniques. Summary statistical analysis and a Spearman's rank correlation was employed to uncover relationships between the independent and dependent variables.

Findings - An empirical examination of data collected indicated that knowledge strategy, organizational culture, information technology, and knowledge leadership as knowledge enablers have a significant positive relationship with KT. Future research is however required to measure transfer within an organization viz-a-viz measure perception of such.

Originality/ value - The work presents a rare glimpse of the relationship between knowledge enablers and KT (particularly in a developing country context) and as such provides utility to policy makers and construction firms to enhance their knowledge capabilities.
\end{abstract}

KEYWORDS: Construction Industry; Enablers; Ghana; Knowledge Sharing; Knowledge Transfer.

\section{INTRODUCTION}


Knowledge is a fundamental asset for firms and organizations (Teece, 1998), and a main resource upon which competitive advantage is founded (Albino et al., 1998; Kogut and Zander, 1992; Nonaka, 1994; Reisman, 2005). Successful knowledge transfer (KT) as a critical factor necessary to improve both productivity (Janis, 2003; Martyniuk et al., 2003) and innovation (Albino et al., 2004; Cohen and Levinthal, 1990; Reisman, 2005). Moreover, knowledge is essential for economic progress whilst international technology transfer is noted as being an important prerequisite requirement for economic development (Hedlund and Nonaka, 1993). Both the acquisition and diffusion of technology foster productive growth in both developed and developing countries (Hoekman et al., 2005). However there are inherent characteristics of knowledge, such as tacit and explicit properties, which makes its transfer inherently difficult (Polanyi, 1967; Nonaka and Takeuchi, 1995; Boisot, 1998). Technological knowledge refers to a class of knowledge about a specific product or production technique and includes the technical skills necessary to use a product or production technique (Erdilek and Rapoport, 1985). Research in technology dynamics suggests that technology can be seen as a human-constructed means for achieving a particular end (Dosi and Grazzi, 2010). Technology transfer therefore conveys the movement of knowledge for the use of a product or production technique. Derakhshani (1984) affirmed technology transfer between companies involves the acquisition, development and utilizations of technological knowledge by a company other than that in which this knowledge originated.

According to Nonaka and Takeuchi (1995), KT should be considered as a transfer of tacit or explicit knowledge in interaction between individuals. Explicit knowledge is cognitive and can be expressed in formal speech or exchanged in data whilst tacit knowledge includes is context related and can only be transferred by individuals during face to face interactions and is embedded within 
organizational contexts (Wilkesmann et al., 2007). O’Dell and Grayson (1998) states that KT enablers include: technology; culture; leadership; and measurement. Davenport and Prusak (1998) suggested that the KT process involves two actions: transmission of knowledge to the potential recipient and knowledge absorption by that recipient to facilitate changes in behavior or the development of new knowledge. Davenport and Prusak (ibid) also identify four knowledge processes in a centralized KM approach, namely: i) knowledge generation (knowledge creation and knowledge acquisition); ii) knowledge codification (storing); iii) KT (sharing); iv) and knowledge application.

Within contemporary practice KT is considered to be the nerve of knowledge management process within an organization. Organizational effectiveness and development can be improved through learning, where knowledge is incorporated into existing business processes in order to form new processes (Armistead, 1999). For example, Khamesh and Jolly (2008) stated that, for long term business survival, creating and accumulating new knowledge is quintessentially important to achieving sustainable advantage (Bou-Llusar and Segarra-Ciprés, 2006). Tan et al., (2006, p.149) further added that the ability to manage knowledge generated from projects and disseminating lessons learned from problem projects within organizations can help to prevent "reinvention of the wheel" and thus avoid the repetition of similar mistakes. Ofek and Sarvary (2001) stipulated that, managing knowledge consists of two processes, knowledge creation and KT. Sexton and Barrett (2004) stated that the management technology is vital to ensuring continuous success of the organization. Kalkhan (2011) emphasized the importance of efficiently transferring knowledge throughout the organization as one prerequisite for an organization to manage knowledge effectively. 
As a commodity, knowledge can be characterized along three dimensions(Boisot, 1998), namely: i) abstraction - the degree to which information is concrete and specific versus generalizable; ii) codification -the extent to which information is actually written down in forms of readable by others; and iii) diffusion - the extent to which the information is circulated throughout the society. For the specific process of technology and knowledge diffusion, Eaton and Kortum (1996) suggest that knowledge spillovers are crucial factors in explaining the growth of advanced economies. Whilst knowledge sustains business more so than than capital, labor or land it remains the most neglected asset. A lack of knowledge limits the ability to understand the role of policy settings in favoring international technology transfer among developed countries; even less is known in the case of developing countries where specific national features may assume an even greater role in explaining the capacity to handle the imported knowledge. To support KT behavior within an organization, management must develop a mechanism which supports a conducive environment for KT. Therefore, this study seeks to identify knowledge enablers as mechanisms to stimulate knowledge creation, knowledge protection and build effective $\mathrm{KS}$ behavior in construction companies. Given the intended scope of study, the work focuses upon verifying the effects of these elements on one aspect of the knowledge management process (i.e. KT as part from sharing of knowledge management process).

\section{CONSTRUCTION TECHNOLOGY AND KNOWLEDGE TRANSFER}

International construction encompasses domestic firms undertaking work or projects from foreign clients, or using human resources, materials, plant and equipment and other construction inputs from foreign countries (Ngowi et al., 2005). Globalization increases competition in domestic markets and also improves access to international markets (Gajendran et al., 2013). Therefore, although the construction industry is 'local' in respect of its regulatory, procurement, political and 
social conditions (Ofori, 2003), it is enmeshed in the wider global business environment - hence, international business and technology transfer theories can also apply to international construction. Much of the construction management literature, explores the benefits of adopting and implementing new technologies (Yang et al., 2012). Construction firms, whether foreign or local, in internationalizing their business need to understand their dynamic capabilities and be innovative (Teece, 2007). Ofori (1994) observed that technology transfer should form part of a technology development programme. In order to promote technological self-reliance, recipients should be involved in the transfer mechanisms. Suitable and hybrid technologies require careful selection to ensure that the technology is: easy to use and transfer; fits with existing technologies; exploiting local resources, contributing to labour productivity and development of the organization/industry; and simultaneously stimulating activities in other sectors (ibid).

Five main elements of international construction 'work' are defined by Howes and Tah (2003) as: i) design consultancy; ii) contracting; iii) equipment supply; iv) construction products/materials; and v) facility management However, Official government information often focuses on four key sectors, namely: i) contracting; ii) consulting; iii) building material production; and iv) plant and equipment - this enables government officials to monitor their interests in international construction more closely by evaluating the individual subsectors separately. According to Mawhinney (2001), this split can help to explain the different approaches to the subject and the perceptible differences in the success of each subsector of the industry. In this study, the official government subdivision is used to evaluate the technology and knowledge (T\&K) deficiencies in the different subsectors. Raftery et al., (1998) reviewed developments in the construction industry in several Asian countries. They observed the increased participation of foreign firms in infrastructure development as a result of: i) globalization and the deregulation of markets 
necessitated by fiscal, technological and managerial constraints in developing countries; and ii) the financial and technical superiority of developed countries. Ofori (2000) observed that Raftery et al., (1998) focused on corporate development but argued that studies on construction industry development need to consider the entire industry. This more holistic perspective is tackled in this paper via an analysis of industry subsectors and professional elements.

Foreign construction firms in developing countries are perceived to bring potential benefits to the host country (Sexton and Barrett, 2004; Bessant and Francis, 2005; Carrillo et al., 2006). The presence of foreign firms creates business opportunities for local firms and also enhances their potential to learn advanced design and construction technology (Ling et al., 2005; Ling et al., 2009). However, van Egmond (2012) noted a need for local T\&K development in developing countries to reduce overreliance on foreign firms. Therefore, Chatterji (1990) argues that technology transfer should be aimed at local capacity building and reduce the reliance on foreign contractors and imported resources. Technology transfer itself encompasses the transfer of physical assets, knowledge and human capabilities to enhance the efficient organization of a construction project and services (Dunning, 1993). Embodied and disembodied knowledge are the most important building blocks for T\&K transfer (Sexton and Barrett, 2004; Carrillo, 1996). Embodied transfer occurs through imports and the replication of building designs, equipment, materials and software for various design and construction methods. Disembodied transfer is primarily based on human skills and human capital seen as crucial for effective transfer, absorption and adaptation to new technologies.

Construction TK transfer is complicated by bicultural barriers and regulatory restrictions (Langford, 2000) and further exacerbated by bespoke construction output requirements and 
production processes for each new project (Kumaraswamy and Shrestha, 2002). Ofori (1994) suggests that TK transfer may occur via foreign-local firm joint ventures (JVs) of a long-term or project-specific nature. Sub-contracting arrangements (SCA) are also possible vehicles of TK transfer but are seen as having some limitations because relationships are often unequal (Devapriya and Ganesan, 2002). Consequently, the World Bank prefers voluntary JV arrangements (Ofori, 1991, 1994;). There is limited literature on project-level technology transfer particularly in SSA. Bakuli (1994) highlighted well-intentioned yet unsuccessful construction industry technology transfer efforts by the Kenyan government due to implementation difficulties and suggested foreign-local JVs as a solution. The capacity/capability implications were not evaluated and the study focused only on the contractor subsector as the unit of analysis. Carrillo (1996) studied JV technology transfer in developing countries using twelve case studies across eight countries (including Nigeria and Lesotho) as SSA countries. The study examined technology transfer mechanisms and found that no specific technology transfer mechanisms existed for the SSA countries; the work was restricted to using foreign contractors as its empirical focus with no evaluation of subsector $\mathrm{T} \& \mathrm{~K}$ gaps and the potential transfers between foreign and local firms. This current study attempts to fill some of these gaps by evaluating the different subsectors and the $\mathrm{T} \& \mathrm{~K}$ transfer potential between foreign and local firms.

\section{Knowledge Transfer in Construction Industry}

Knowledge possessed by participants in a construction process represent the knowledge assets for organizations. Eliufoo (2007) critically analyzed knowledge assets possessed by participants in construction and identified considerations such as: i) constructability (e.g. cost, time and quality matters, maintenance, safety and productivity); and ii) suitability of the final building or infrastructure product (e.g. durability, comfort, marketability of final product, regulatory matters 
and insurance matters). These knowledge assets must be manage and disseminating to gain maximum advantage. Yet, the construction sector is infamously known for lacking a wellfunctioning system for collecting and distributing knowledge and technology.

\section{Knowledge Transfer Process}

Szulanski (1996) introduced a framework for intra firm KT. Through a questionnaire survey, Holsapple and Joshi (2001) critically analyzed Szulanski (1996)'s model. The model identified four stages in the KT process: i) initiation; ii) implementation; iii) ramp -up; and iv) integration. Initiation comprises all events that lead to the decision to transfer. According to Szulanski (1996), KT occurs only if both need and knowledge which meet the need are available. Implementation begins with the decision to transfer is taken - at this stage, flow of knowledge between the recipient and the source, establishes social ties leading to customizing of transfer to suit the recipient's needs. Then the recipient begins to use the transferred knowledge. While attempting to identify and resolve problems of new knowledge, expected post-transfer performance will be achieved at the ramp-up stage. Finally, the transferred knowledge will become stored and institutionalized at the integration stage.

Argote and Ingram (2000)'s model affords a much a good basis for the KT process but it fails to specify a step by step process. For instance, the model encourages movement of networks to minimize knowledge spill over to other firms but it does not suggest methods or mechanisms to do that. Szulanski (1996), Sverlinger (2000) and Liyanage et al., (2009), provide more reasonable models for knowledge transference and do not conflict with other knowledge management aspects. These three models have similarities with each other. The initiation stage of Szulanki's (1996) model is similar to the awareness stage proposed in the model by Liyanage et al., (2009). 
Sverlinger (2000) introduced three stages as: i) knowledge and information acquisition, ii) information distribution; and iii) retrieval of information and knowledge while Liyanage et al., (2009) introduced two stages called acquisition and transformation for the same purpose. However, Szulanski (1996) covered all those things through a single stage called implementation. Integration, association and organization memory have the same purpose in each model. Both Szulanski (1996) and Sverlinger (2000) have a stage for problem solving as ramp-up and retrieval of information while such is not apparent in the model proposed by Liyanage et al., (2009). However, it has an application stage which is already covered by alternatives stages in other two models. Therefore, this research takes Szulanski (1996)'s KT process (initiation, implementation, ramp-up and integration) as the KT process for further analysis because it covers all the transfer stages while Liyanage et al., (2009) fails to include a ramp-up stage whilst Sverlinger (2000) does not cover the initiation stage.

\section{KNOWLEDGE TRANSFER ENABLERS}

A synthesis of academic discourse and empirical results seeks to identify the relationship that exists between knowledge enablers and KT. The final model produced then combines knowledge enablers as independent variables and KT as the dependent variable. To identify the knowledge enablers, four thematic categories were obtained from the literature, namely: organizational culture; information technology; knowledge strategy; and knowledge leadership.

\section{Organizational Culture}

According to Wen-bao (2007) organizational culture is the common belief, conduct rules and values shared by all organizational members. Organizational culture can be conveniently classified into three types: i) bureaucratic culture - where most of the work in an organization is standardized 
and operates on the basis of control and power. Tasks are completed in proper sequence and enterprise ethic is specially emphasized; ii) innovative culture - where work in an organization is challenging and innovative. Here members of the organization are encouraged to be adventurous and take the initiative; and iii) supportive culture - where an open and harmonious working environment if fostered. Participation, teamwork and interpersonal relationship are specially emphasized. Jennex and Olfman (2005) state that: "an organizational culture that supports learning and the sharing and use of knowledge” encapsulates characteristics such as altruism, reciprocity, trust, repute, openness, solidarity, sociability, motivation and commitment. Organizational culture is a system shared by all organizational members to distinguish it from other organizations.

\section{Information Technology}

According to Brink (2003), technology support refers to knowledge sharing (KS) by enabling the communication, collaboration, provision of accumulated knowledge storing and retrieval of knowledge. Mohamed et al., (2009) found that information technology may serve as a cost effective and expedient means of acquiring, storing, sharing and transferring knowledge but it requires human motive and willingness to engage in KM. Some researchers contend that IT plays four different roles in knowledge management: i) obtaining knowledge; ii) defining, storing, indexing and categorizing; iii) seeking to identify related content; and iv) flexibly expressing the content based on the various utilization background (Safa et al., 2006; Cavana, et al., 2001; Zack, 1999). Example of IT facilities support is by providing groupware, online databases, the intranet of things and virtual communities of practice (Lin, 2007). 


\section{Knowledge Leadership}

According to Nonaka and Toyama (2005) knowledge leadership is vital knowledge creation and requires active commitment from all the members of the organization. Leadership links the context and the process (Nonaka et al., 2000). Leadership plays various roles in the knowledge creation process such as: providing vision; creating, energizing and connecting; and enabling and promoting the continuous spiral of knowledge creation. Von Krogh et al., (2000) said that: "managers in the knowledge economy will be figuring out what their company ought to know for the future." Knowledge leadership is an important enabler that helps KT and enhances knowledge creation in the company.

\section{Knowledge Strategy}

Strategies for KT, knowledge creation and customer focus are considered by organizations when developing and implementing KM (Wiig, 1997). The approach adopted is associated with business objectives, goals, plans, policies, decisions making and the kind of organization the company is oriented to be regards its shareholders, employees, customers and communities (Andrews, 1992). From the discussion above, it is appropriate to hypothesize that:

Hypothesis 1; there exist a strong positive relationship between KT and: (H1a). knowledge strategy, (H1b). organizational culture, (H1c). information technology and (H1d). knowledge leadership.

\section{RESEARCH APPROACH}

Data collection for this study was undertaken with Ghanaian construction professionals in the third quarter of 2014. The target group of respondents include design and construction professionals 
from construction projects involving TT initiatives. The research only solicited the perceptions of the transferee (Ghana) since TT initiatives are ultimately undertaken for the purpose of improving knowledge levels and enhancing the industry capacity of host participants. Thus, individuals from the host country were considered to be the best respondents to evaluate the importance and effectiveness of variables pertaining to the TT process and concomitant outcomes it can potentially generate. Determining the exact population of potential respondents who fitted the description for this target group was difficult to establish because no records of such currently exist. Hence, purposive and snowballing non-probability sampling techniques were adopted. Purposive sampling refers to strategies in which the researcher exercises judgment about who will provide the best perspective on the phenomenon of interest, and then intentionally invites those specific perspectives into the study. Purposive sampling is useful for situations where a targeted sample must be reached quickly and where sampling for proportionality is not the primary concern. With a purposive sample, the opinions of the target population can be readily accrued but this elevates the risk of overweighting subgroups in the population that are more readily accessible. Snowball sampling is a useful technique for finding the research subject (Atkinson and Flint, 2001). This strategy may be viewed as a response to overcome the problems associated with concealed or hardto-reach populations. The process is based upon the assumption that a 'link' exists between the initial sample and others in the same target population and facilitates a series of referrals to be made within a circle of acquaintance (Berg, 1988; Atkinson and Flint, 2001). Hence, snowball sampling was used for identifying respondents with rich information that are relevant to the study. A total of 120 survey questionnaires were distributed and 94 were obtained, representing a response rate of 78 percent. Since there is no scientifically proven minimally acceptable response rate. A response rate of 60 percent has been used as the threshold of acceptability by some and has face validity as a measure of survey quality; however, similar to $p<0.05$ in statistical comparisons, 
60 percent is only a 'rule of thumb' that masks a more complex issue (Johnson and Wislar, 2012). As a result, our response rate is regarded as relatively high, which concur with previous studies (Al-Gharibeh, 2011), since our target respondents are key stakeholders in construction and they are supposed to be too busy to respond to questionnaires. The questionnaire survey contained two distinct sections. The first section solicited descriptive statistics on the participating respondent and the project they have been involved with where TT programs were integrated. This section enabled the establishment of a comprehensive respondent background information on their profile (i.e. firm status, firm existence and experience of professional). The second section included questions relating to the knowledge management enablers of TT process including: organizational culture; information technology; knowledge leadership; and knowledge strategy. Respondents (e.g, project managers, contractors, quantity surveyors) were requested to provide a rating for these variables measured on a five-point Likert item ranging from ' $1=$ Not Significant' to ' $5=$ Very Significant'. Questionnaires on KT were adapted and modified from previous studies (Ngoc, 2005; Wilkesmann et al., 2007). Thus, based on the five-point Likert scale, a knowledge enabler was deemed critical or important if it had a mean of 3.5 or more. When two or more enablers have the same mean, the one with the lowest standard deviation was assigned the highest important ranking (Field, 2005). Data obtained from both sections was utilized to ensure that variables were perceived to be sufficiently important to be considered as essential knowledge management enabler for formulating the conceptual framework. Statistical techniques adopted included descriptive analysis, mean score rankings and the Spearman's rank correlation (Ling, 2002; Field, 2005).

\section{DATA ANALYSIS AND RESULTS}

The results are divided into two parts. The first part reports upon the demographic profile of the Ghanaian construction sector and professionals who participate in TT programs. The second part 
reports upon the key significant relationship of knowledge management enablers within the TT process.

\section{Demographic profile}

\section{Firm status}

Owusu-Manu (2008) has argued that the effect of legal organization can affect the behavior of the firm activity. The conventional types of legal organization considered in this study were: enterprises/sole proprietorship, private limited liability and partnerships/joint venture. These types of firms have been mentioned by Owusu-Manu (ibid) as popular legal forms of businesses in both developed and developing countries. When the respondents were asked to indicate the type of legal organization of their firms, a high majority of the respondent representing 57.4 percent were observed to be operating as private limited liability firms (PLF), 28.7 percent also indicated enterprises/sole proprietorship and the remaining 13.8 percent indicated partnerships/joint venture (refer to Table 1).

\section{<Insert Table 1 about here>}

This illustrates that construction firms are largely private owned within Ghana. The results emphasized the perceived advantage of PLF as a good signal that portrays credibility and formality of operations or represents an indication of future growth within the firm (Cassar, 2004). Storey (1994) and Cassar (2004) argued that while some may consider the benefits of PLF, the limited liability gain is fictional in reality. PLFs predominate in Ghana because construction industry firms belong to a sector in which the government is the largest employer operating with public procurement regulations that do not recognize sole proprietorship. Sole proprietorships are most 
suitable where the market is limited, localised and where customers give importance to personal attention and individuals prefer owning their businesses as a result of prestige and personal gain/profits.

\section{Years of a Firm's Existence}

The years of a firm's existence represents a critical factor in the life of every business establishment. Empirical studies conducted have investigated the relationship between age of firm and the firm's real activity variables, including growth, financing pattern and employment. These studies have addressed the question of what happens to a firm as it ages. For instance, Evans (1987) revealed that the growth rate of firms and the volatility of growth are both negatively associated with firm age. Cabral and Mata (2003) demonstrated that the firm size distribution moves towards the right hand side as firms' age. In this regard, Stinchcombe (1965) suggested that older firms are more experienced, have learned more over time and are not susceptible to the liabilities of newness and have the benefits of better performance. Previously, other authors have considered age of vendor firms as a proxy measure for the reduction of asymmetric information between a firm and its financiers (Elliehausen and Wolken, 1993; Bergerad and Udellc, 1998). Drawing upon these experiences, and anchored on the assumption that, the age of the firm would also affect firms' social obligations, it was important to explore the age levels of the firms that were involved in the survey.

\section{<Insert Table 2 about here>}

Table 2 illustrates that: 33.0 percent of surveyed firms have been in existence for $\leq 10$ years; 14.9 percent $>10 \leq 20$ years; 37.2 percent $>21 \leq 30$ years; and 14.9 percent $>30$ years. The results 
indicate that the sample participating firms have reasonable experience. Also, the age of the firm will determine the experiences of its employees in the acquisition of knowledge and technology in the TT process.

\section{Experience of Professional}

A respondent's years of experience within an organisation is necessary as respondents acquire more knowledge in time. Moreover, a respondent's working experience can indicate their knowledge and TT capabilities.

\section{<Insert Table 3 about here>}

Table 3 reveals that 22.3 percent of survey respondents have $<5$ years working experience. However, a high majority of 43.6 percent of respondents have working experience $>5 \leq 10$ years; 11.7 percent $>11 \leq 15$ years; and 22.3 percent $>16 \leq 20$ years. The results indicate that survey respondents have reasonable experience and a plausible conclusion therefore is that the respondents are vexed in TT process. This spread of respondent years of experience should provide a balanced view of how the TT process is perceived by the Ghanaian construction sector.

\section{Reliability Test}

Reliability test was performed to measure the consistency of respondents' responses to all the enablers of knowledge transfer in the questionnaire. The Cronbach's Alpha reliability coefficient of the KT was 0.757 and independent variables were: knowledge strategy (0.822), organizational culture (0.835), information technology (0.878), and knowledge leadership (0.899). The results 
indicate that the Cronbach's Alpha for all the variables ranged from 0.70 to 0.90 . In particular, reliabilities of less than 0.60 are considered to be poor; those in the 0.70 range are acceptable; and those over 0.80 are good (Cavana et al., 2001). Drawing on from the above, our results revealed that the Cronbach's Alpha values are over the critical point of 0.70, which suggest that the survey's reliability is acceptable.

<Insert Table 4 about here>

Table 4 illustrates that because all the factors affecting KT enablers of TT process (i.e. knowledge strategy, organizational culture, information technology and knowledge leadership) have mean values above the accepted population mean of 3.5 (drawing from Ling, 2003), it is plausible to conclude that they are necessary to the performance of Ghanaian construction firms as well as the economy as a whole. The standard errors associated with all the mean values were relatively closer to zero suggesting that the sample chosen is an accurate reflection of the population. The analysis also revealed that the standard deviations of a large majority are less than 1.0 signaling that, there is little variability in the data collected and consistency in agreement among the respondents. Thus, based on the descriptive statistics alone using the mean score ranking, it could be confidently concluded that the independent variable (KT factors) identified through literature and interviews reflects the views and perspective of the target respondents.

\section{<Insert Table 5 about here>}

The relationship between KT and knowledge enablers was investigated using spearman's rank correlation to aforementioned hypothesis (refer to Table 5); the results revealed that there was a strong, positive correlation between $\mathrm{KT}$ and knowledge strategy $\left(r_{s}=0.618, p<0.05\right)$; 
organizational culture $\left(r_{s}=0.691, p<0.05\right)$; information technology $\left(r_{s}=0.702, p<0.05\right)$; and knowledge leadership $\left(r_{s}=0.721, p<0.05\right)$. As a result, the null hypothesis can be rejected at a significance level of 0.05 .

These results confirm the existence of a significant relationship between KT and knowledge strategy; organizational culture; information technology; and knowledge leadership. Strategies such as KT strategy, knowledge creation strategy and customer focus strategy are some of the strategies which organizations consider as knowledge management (KM) adopting strategies (Wiig, 1997; Manasco, 1996). According to Wen-bao (2007) organizational culture is the common belief, conduct rules and values shared by all members within an organization. Previous studies (Lu et al., 2006; Kim and Lee, 2006; Lee and Choi, 2003; Goh, 2002) found that teamwork and collaboration are important cultural aspects that support $\mathrm{KS}$ in an organization which considers KT as a part from KS. Furthermore, information technology is also an important enabler that supports KT. The results of data analysis indicate that information technology facilitates a process of KT. According to Brink (2003), technology support refers to KS by enabling communication and collaboration by storing accumulated knowledge and retrieve knowledge of such. Ahmed et al., (2009) found that information technology may serve as a cost effective and fast medium to acquire, store, share and transfer knowledge but it needs human motive and willingness to engage in KM. Lastly, according to Nonaka and Toyama (2005) leadership is a vital knowledge creating which requires active commitment from all the members of the organization.

\section{CONCLUSIONS AND FUTURE RESEARCH}

The issue of knowledge and technology transfer has been a great interest area for academics, policy makers, and industrialists in both developed and developing countries. This study's findings have 
implications for public policy, which considers technology and KT as a key area within the broader domain of innovation policy. Also, the paper has reviewed the current state of construction technology and KT and utilization within the industry. Based on the findings, the research reveals that there is a key significant relationship of knowledge enablers on KT in the construction industry. The verified hypothesis shows that knowledge enablers (knowledge strategy; organizational culture; information technology; and knowledge leadership) supports KT. However, the information technology enabler proved to be the most important enabler for KT; followed by knowledge strategy.

Both government and industry policy should aim to strategically develop local firms to ensure that they can meaningfully collaborate with foreign competition through any transfer mechanisms. This development must look specifically at the knowledge base of local firms whose experience and capabilities exacerbates their inability to compete and handle complex and large scale projects. This study brings together pertinent construction technology and KT enablers and KT process in developing countries specifically in Ghana. Several analytical approaches adopted reveal the complexities involved in technology and KT in a developing countries context. Technology and knowledge has also been viewed from product, process and managerial technology perspectives; again a more holistic approach to TT than most previous studies which tend to focus on only one or two of the technologies. Above all, this study goes beyond just identifying technology and knowledge gaps and related challenges to explain why and how to facilitate technology and KT, particularly in Ghanaian construction industry. In view of the scarcity of such studies in developing countries, the findings enhance our understanding of the technology and knowledge issues. The study does however have limitations, although the findings contribute to widening the literature base on technology and knowledge in developing countries, the work could not be generalized to 
every industry and therefore should be expanded to cover other industries in order to share experiences and approaches to TT. Moreover, the identification of the key variables that could facilitate technology and KT will help to create a platform for more broadly based and longitudinal studies in the future. Future work should however aim to measure KT within a construction business via-a-vis measure perceptions of such - perhaps using case studies as a basis for such. 


\section{REFERENCES}

Ahmed, H., Jalil, J., and Rus, A. M., (2009) The Effect of Knowledge Enablers to Knowledge Acquisition: Evidence from Higher Education in Malaysia.

Albino, V., Garavelli, A. C., and Gorgoglione, M., (2004) Organization and Technology in Knowledge Transfer, Benchmarking: An International Journal, Vol. 11, No. 6, pp. 584600.DOI: 10.1108/14635770410566492.

Albino, V., Garavelli, A. C., and Schiuma, G., (1998) Knowledge Transfer and Inter-firm Relationships in Industrial Districts: The Role of the Leader Firm, Technovation, Vol. 19, No. 1, pp. 53-63. DOI: 10.1016/S0166-4972(98)00078-9.

Al-Gharibeh, K. M., (2011) The Knowledge Enablers of Knowledge Transfer: An Empirical Study in Telecommunications Companies, IBIMA Business Review, Vol. 20, pp. 13 - 26. DOI: $10.5171 / 2011.328944$.

Andrews, J., (1992) Globalization and Technology Transfer: Joint Construction Venture, Paper Presented at the Building Seminar, Singapore, 30 January.

Argote, L., and Ingram, P., (2000) Knowledge Transfer: A Basis for Competitive Advantage in Firms, Organizational Behaviour and Human Decision Processes, Vol. 82, No. 1, pp. 150169. DOI: 10.1006/obhd.2000.2893.

Armistead, C., (1999) Knowledge Management and Process Performance, Journal of Knowledge Management, Vol. 3, No. 2, pp. 143-157. DOI: 10.1108/13673279910275602.

Atkinson, R., and Flint, J., (2001) Accessing Hidden and Hard- to-Reach Populations: Snowball Research Strategies, Social Research Update 33, Guildford: University of Surrey.

Bakuli, D. L., (1994) Pitfalls in Technology Transfer: Kenya's Construction Industry, World Development, Vol. 22, No. 10, pp. 1609-1612. DOI: 10.1016/0305-750X (94)90042-6. 
Berg, S., (1988) Snowball Sampling, in Kotz, S., and Johnson, N. L., (Eds.) Encyclopedia of Statistical Sciences, Vol. 8, pp. 529-532.

Bergerab, A. N., and Udellc, G.F., (1998) The Economics of Small Business Finance: The Roles of Private Equity and Debt Markets In the Financial Growth Cycle, Journal of Banking and Finance, Vol. 22, No. 6, pp. 613-673. DOI: 10.1016/S0378-4266(98)00038-7.

Bessant, J., and Francis, D., (2005) Transferring Soft Technologies: Exploring Adaptive Theory, International Journal of Technology and Management and Sustainable Development, Vol. 4, No. 2, pp. 93-112.DOI: 10.1386/ijtm.4.2.93/1.

Boisot, M. H., (1998) Knowledge Assets: Securing Competitive Advantage in the Information Economy, Oxford: Oxford University Press. ISBNs: 9780191589348.

Bou-Llusar, J. C., and Segarra-Cipres, M., (2006) Strategic Knowledge Transfer and its Implications for Competitive Advantage: An Integrative Conceptual Framework, Journal of Knowledge Management, Vol. 10, No. 4, pp. 100-112. DOI: 10.1108/13673270610679390.

Brink, P. V. D., (2003) Social, Organizational and Technological Condition that Enable Knowledge Sharing, a Ph.D. Thesis presented to Faculty of Technology, Policy and Management at the Delft University of Technology, Delft, The Netherlands.

Cabral, L. M. B., and Mata, J., (2003) On the Evolution of the Firm Size Distribution: Facts and Theory, American Economic Review, Vol. 93, No. 4, pp. 1075-1090. DOI: $10.1257 / 000282803769206205$.

Carrillo, P. M., Robinson, H. S., Anumba, C. J., and Bouchlaghem, N. M., (2006) A Knowledge Transfer Framework: The PFI Context, Construction Management and Economics, Vol. 24, No. 10, pp. 1045-1056. DOI: 10.1080/01446190600799224. 
Carrillo, P., (1996) Technology Transfer on Joint Venture Projects in Developing Countries, Construction Management and Economics, Viol. 14, No. 1, pp. 45-54. DOI: 10.1080/01446199600000006.

Cassar, G., (2004) Financing of Business Start-Ups, Journal of Business Venturing, Vol. 19, No. 2, pp. 261-283. DOI: 10.1016/S0883-9026(03)00029-6.

Cavana, R. Y., Delahaye, B. L., and Sekaran, U. (2001) Applied Business Research: Qualitative and Quantitative Methods, John Wiley and Sons: Australia.

Chatterji, M., (1990) Technology Transfer in the Developing Countries, London: Macmillan Press.

Cohen, W. M., Levinthal, D. A., (1990) Absorptive Capacity: A New Perspective on Learning and Innovation, Administrative Science Quarterly, Vol. 35, No. 1, pp. 128-152. DOI: $10.2307 / 2393553$.

Davenport, T. H., and Prusak, L., (1998) Working Knowledge: How Organizations Manage What They Know, Boston, MA: Harvard Business School Press. ISBNs: 9780585056562.

Derakhshani, S., (1984) Factors Affecting Success in International Transfer of Technology - A Synthesis and a Test of New Contingency Model, The Developing Economics, Vol. 22, No. 1, pp. 27-47. DOI: 10.1111/j.1746-1049.1984.tb00650.x.

Devapriya, K. A. K., and Ganesan, S., (2002) Technology Transfers Through International Subcontracting in Developing Countries, Building Research and Information, Vol. 30, No. 3, pp. 171-182. DOI: 10.1080/09613210110117593.

Dosi, G., and Grazzi, M., (2010) On the Nature of Technologies: Knowledge, Procedures, Artifacts and Production Inputs, Cambridge Journal of Economics, Vol. 34, No. 1, pp. 173-184. DOI: https://doi.org/10.1093/cje/bep041. 
Dunning, J. H., (1993) Multinational Enterprises and the Global Economy, Wok-ingham, England and Reading, Mass:Addison Wesley.

Eaton, J., and Kortum, S., (1996) Trade in Ideas Patenting and Productivity in the OECD, Journal of International Economics, Vol. 40, No. 3-4, pp. 251-278. DOI: 10.1016/00221996(95)01407-1.

Eliufoo, H., (2007) Managing Knowledge Transfer Effectively, In: B.A. Atkin and J. Borgbrant, eds. 4th Nordic Conference on Construction Economics and Organization: Development Processes in Construction Management, Sweden 14-15 June 2007. Luelea: University of Technology, pp. 105-118.

Elliehausen, G. E., and Wolken, J. D., (1993) Banking Markets and the Use of Financial Services by Small and Medium-Sized Businesses Staff Studies 160, Washington: Board of Governors of the Federal Reserve System.

Erdilek, A., and Rapoport, A., (1985) Conceptual and Measurement Problems in International Technology Transfer, In: A.C. Samli, Editor, Technology Transfer, Greenwood, Westport, CT, pp. 252.

Evans, D. S., (1987) The Relationship Between Firm Growth Size and Age: Estimates for 100 Manufacturing Industries, Journal of Industrial Economics, Vol. 35, No. 4, pp. 567-581. DOI: $10.2307 / 2098588$.

Field, A., (2005) Discovering statistics, using SPSS for windows, London: Sage Publications. Gajendran, T., Brewer, G., and Marimuthu, M., (2013) Internationalization of Construction Business and E-commerce: Innovation, Integration and Dynamic Capabilities, The Australian Journal of Construction Economics and Building, Vol. 13, No. 2, pp. 1-17. 
Goh, S. C., (2002) Managing Effective Knowledge Transfer: An Integrative Framework and Some Practice Implications, Journal of Knowledge Management, Vol. 6, No. 1, pp. 23-30. DOI: $10.1108 / 13673270210417664$.

Hedlund, G. and Nonaka, I. (1993) Models of Knowledge Management in the West and Japan, in Lorange, P., Chakravarthy, B., Roos, J. and Van de Ven, A. (Eds), Implementing Strategic Processes: Change, Learning and Co-operation, Blackwell, Oxford, pp. 420. ISBN: 0-63118565-8.

Hoekman, B. M., Maskus, Keith E., and Saggi, K., (2005) Transfer of Technology to Developing Countries: Unilateral and Multilateral Policy Options, World Development, , Vol. 33, No. 10, pp. 1587-1602. DOI: 10.1016/j.worlddev.2005.05.005.

Holsapple, C.W., and Joshi, K. D., (2001) Organizational Knowledge Resources, Decision Support Systems, Vol. 31, No. 1, pp. 39-54. DOI: 10.1016/S0167-9236(00)00118-4.

Howes, R., and Tah, J. H. M., (2003) Strategic Management Applied to International Construction, Thomas Telford, London.

Janis, F. T., (2003) Technology Transfer Emerging Issues "High Impact Trends", Journal of Technology Transfer, Vol. 28, No. 3-4, pp. 241-249. DOI: 10.1023/A: 1024936710657.

Jennex, M., and Olfman, L., (2005) Assessing Knowledge Management Success, International Journal of Knowledge Management, Vol. 1, No. 2, pp. 33-49. DOI: $10.4018 / \mathrm{jkm} .2005040104$.

Johnson, T. P., and Wislar, J. S., (2012) Response Rates and Nonresponse Errors in Survey, The Journal of the American Medical Association, Vol. 307, No. 17, pp. 1802-1806. DOI: 10.1001/jama.2012.3532.

Kalkhan, V. D., (2011) Knowledge Continuity Management Process in Organisations, Journal of Business and Economics Research, Vol. 4, No. 3, pp. 41-46. 
Khameseh, H. M. and Jolly, D. R., (2008) Knowledge Transfer in Alliances: Determinant Factors, Journal of Knowledge Management, Vol. 12, No. 1, pp. 37-50. DOI: $10.1108 / 13673270810852377$.

Kim, S., and Lee, H., (2006) The Impact of Organizational Context and Information Technology on Employee Knowledge Sharing Capabilities, Public Administration Review, Vol. 66, No. 3, pp. 370-385. DOI: 10.1111/j.1540-6210.2006.00595.x.

Kogut, B., and Zander, U., (1992) Knowledge of the Firm, Combinative Capabilities and the Replication of Technology, Organization Science, Vol. 3, No. 3, pp. 383-397. DOI: http://www.jstor.org/stable/2635279.

Kumaraswamy, M. M., and Shrestha, G. B., (2002) Targeting 'Technology Exchange' for Faster Organizational and Industry Development, Building Research and Information, Vol. 30, No. 3, pp. 183-195. DOI: 10.1080/09613210110115216.

Langford, D., (2000) The Influence of Culture on Internationalization of Construction, Presented at 2nd International Conference on Construction in Developing Countries, Botswana. In A. B. Ngowi and J. Ssegawa (Eds.), In Proceedings of the 2nd International Conference on Construction in Developing Countries, Faculty of Engineering and Technology, University of Botswana, pp. 12-21.

Lee, H., and Choi, B., (2003) Knowledge Management Enablers, Processes and Organizational Performance: An Integrative View and Empirical Examination, Journal of Management Information System, Vol. 20, No. 1, pp. 179-228. DOI: 10.1080/07421222.2003.11045756.

Lin, H. -F., (2007) Knowledge Sharing and Firm Innovation Capability: An Empirical Study, International Journal of Manpower, Vol. 28, No. 3/4, pp. 315-332. DOI: $10.1108 / 01437720710755272$. 
Ling, F. Y. Y., Ibbs, C. W., and Cuervo, J. C. (2005) Entry and Business Strategies Used by International Architectural, Engineering and Construction Firms in China, Construction Management and Economics, Vol. 23, No. 5, pp. 509-520. DOI: 10.1080/01446190500040141.

Ling, F. Y. Y., Pham, V. M. C., and Hoang, T. P., (2009) Strengths, Weaknesses, Opportunities, and Threats for Architectural, Engineering, and Construction Firms: Case Study of Vietnam, Journal of Construction Engineering and Management, Vol. 135, No. 10, pp. 1105-1113. DOI: 10.1061/ (ASCE) CO.1943-7862.0000069.

Ling, Y. Y., (2003) A Conceptual Model for the Selection of Architects by Project Managers in Singapore, International Journal of Project Management, Vol. 21, No. 2, pp. 135-144. DOI: 10.1016/S0263-7863(02)00014-5.

Liyanage, C., Elhag, T., Ballal, T. and Li, Q., (2009) Knowledge Communication and Translation - A Knowledge Transfer Model, Journal of Knowledge Management, Vol. 13, No. 3, pp. 118-131. DOI: 10.1108/13673270910962914.

Lu, L., Leung, K., and Koch, P. T., (2006) Managerial Knowledge Sharing: The Role of Individual, Interpersonal, and Organizational Factors, Management and Organization Review, Vol. 2, No. 1, pp. 15-41. DOI: 10.1111/j.1740-8784.2006.00029.x.

Manasco, B., (1996) ‘Leading Firms Develop Knowledge Strategies’, Knowledge Inc., Vol.1, No. 6, pp.9-26.

Martyniuk, A. O., Jain, R. K., and Stone, H. J., (2003) Critical Success Factors and Barriers to Technology Transfer: Case Studies and Implications, International journal of Technology Transfer and Commercialization, Vol. 2, No. 3, pp. 306-327. DOI: 10.1504/IJTTC.2003.003173.

Mawhinney, M., (2001) International Construction, Blackwell Science, Oxford; Malden, MA. 
Mohamed, A. S., Sapuan, S. M., Megat Ahmad, M. M. H., Hamouda, A. M. S., and Hang Tuah, B. T., (2009) The Effect of Technology Transfer Factors on Performance: An Empirical Study of Libyan Petroleum Industry, American Journal of Applied Sciences, Vol. 6, No. 9, pp. 1763-1769.

Ngoc, P. T. B., (2005) An Empirical Study of Knowledge Transfer within Vietnam's IT Companies, Working paper, University of Hanoi, Switzerland.

Ngowi, A. B., Pienaar, E., Talukhaba, A., and Mbachu, J., (2005) The Globalization of the Construction Industry: A Review, Building and Environment, Vol. 40, No. 1, pp. 135141. DOI: 10.1016/j.buildenv.2004.05.008.

Nonaka, I., and Takeuchi, H., (1995) The Knowledge Creating Company: How Japanese Companies Create the Dynamics of Innovation, Oxford University press, New York.

Nonaka, I., and Toyama, R., (2005) The Theory of the Knowledge - Creation Firm: Subjectivity, Objectivity and Synthesis, Industrial and Corporate Change, Vol. 14, No. 3, pp. 419436.DOI: https://doi.org/10.1093/icc/dth058.

Nonaka, I., (1994) A Dynamic Theory of Organizational Knowledge Creation, Organization Science, Vol. 5, No. 1, pp. 14-37. DOI: http://www.jstor.org/stable/2635068.

Nonaka, I., Toyama, R., and Konno, N., (2000) SECI, Ba and Leadership: A Unified Model of Dynamic Knowledge Creation, Long Range Planning, Vol. 33, No. 1, pp. 5-34. DOI: 10.1016/S0024-6301(99)00115-6.

O’Dell, C., and Grayson, C. J., (1998) If Only We Knew What We Know: Identification and Transfer of Internal Best Practices, California Management Review, Vol. 40, No. 3, pp.154-174. 
Ofek, E. and Sarvary, M., (2001) Leveraging the Customer Base: Creating Competitive Advantage Through Knowledge Management, Management Science, Vol. 47, No. 11, pp. 1441-1456. DOI: 10.1287/mnsc.47.11.1441.10249.

Ofori, G., (1991) Programmes for Improving the Performance of Contracting in Developing Countries: A Review of Approaches and Appropriate Options, Construction Management and Economics, Vol. 9, No. 1, pp. 19-38. DOI: 10.1080/01446199100000003.

Ofori, G., (1994) Construction Industry Development: Role of Technology Transfer, Construction Management and Economics, Vol. 12, No. 5, pp. 379-392. DOI: 10.1080/01446199400000049.

Ofori, G., (2000) Globalization and Construction Industry Development: Research Opportunities, Construction Management and Economics, Vol. 18, No. 3, pp. 257-262. DOI: 10.1080/014461900370627.

Ofori, G., (2003) Frameworks for Analyzing International Construction, Construction Management and Economics, Vol. 21, No. 4, pp. 379-391. DOI: 10.1080/0144619032000049746.

Owusu-Manu, D., (2008) Equipment Investment Finance Strategy for Large Construction Firms in Ghana", PhD Dissertation submitted to the Department of Building Technology, Kwame Nkrumah University of Science and Technology, Kumasi-Ghana: 2008.

Polanyi, M., (1967) The Tacit Dimension. Anchor, Garden City, New York.

Raftery, J., Pasadilla, B., Chiang, Y. H., Hui, E. C. M., and Tang, B.-S. (1998) Globalization and Construction Industry Development: Implications of Recent Developments in the Construction Sector in Asia, Construction Management and Economics, Vol. 16, No. 6, pp. 729-737. DOI: 10.1080/014461998372024. 
Reisman, A., (2005) Transfer of Technologies: A Cross-disciplinary Taxonomy, Omega: The International Journal of Management Science, Vol. 33, No. 3, pp. 189-202. DOI: 10.1016/j.omega.2004.04.004.

Safa, M. S., Shakir, F., and Boon, O. K., (2006) Knowledge Management: Practice and Performance of NGO in Maldives, International Journal of Management and Entrepreneurship, Vol. 2, No. 1, pp. 69-86.

Sexton, M., and Barrett, P., (2004) The Role of Technology Transfer in Innovation within Small Construction Firms, Engineering Construction and Architectural Management, Vol. 11, No. 5, pp. 342-348. DOI: 10.1108/09699980410558539.

Stinchcombe, A. L., (1965) Social Structure and Organizations, In: J. G. (Ed). Handbook of Organizations, March. Chicago: Rand McNally.

Storey, D. J., (1994) Understanding the Small Business Sector, London, Routledge.

Sverlinger, P. O. M., (2000) Managing Knowledge in Professional Service Organisations, Thesis (PhD). Chalmers University of Technology: Sweden. Liyanage, C., Elhag, T., Ballal, T. and Li, Q., 2009. Knowledge Communication and Translation - A Knowledge Transfer Model, Journal of Knowledge Management, Vol. 13, No. 3, pp. 118-131.

Szulanski, G., (1996) Exploring Internal Stickiness: Impediments to the Transfer of Best Practice within the Firm, Strategic Management Journal, Vol. 17, No. S2, pp. 27-43. DOI: 10.1002/smj.4250171105.

Tan, H. C., Carrillo, P., Anumba, C., Kamara, J. M., Bouchlaghem, D., and Udeaja, C., (2006) Live Capture and Reuse of Project Knowledge in Construction Organisations, Knowledge Management Research and Practice, Vol. 4, No. 2, pp. 149-161. DOI: 10.1057/palgrave.kmrp.8500097. 
Teece, D. J., (2007) Explicating Dynamic Capabilities: The Nature and Micro Foundations of (Sustainable) Enterprise Performance, Strategic Management Journal, Vol. 28, No. 13, pp. 1319- 1350. DOI: 10.1002/smj.640.

Teece, D. J., (1998) Capturing Value from Knowledge Assets: The New Economy, Markets for Know-How, and Intangible Assets, California Management Review, Vol. 40, No.3, pp. $55-79$.

Van Egmond, E., (2012) Construction Technology Development and Innovation, In G. Ofori (Ed.), New perspectives on Construction in Developing Countries, Spon: London, pp. $185-228$.

Von Krogh, G., Ichijo, K., and Nonaka, I., (2000) Enabling Knowledge Creation: How to Unlock the Mystery of Tacit Knowledge and Release the Power of Innovation, Oxford Press.

Wen-bao, L., (2007) The Effect of Knowledge Sharing Model Expert System with Application, Journal of Technology Transfer, Vol. 134, No. 2, pp. 508-1521.

Wiig, K. M., (1997) Knowledge Management: Where Did It Come from and Where Will It Go?, Expert Systems with Applications, Vol. 13, No. 1, pp. 1-14. DOI: 10.1016/S09574174(97)00018-3.

Wilkesmann, U., Wilkesmann, M., and Virgillito, A., (2007) Requirements for Knowledge Transfer in Hospital: How Can Knowledge Transfer be Supported in Hospitals?, Discussion Papers des Zentrums fur Weiterbildung Universitat Dortmund, ISSN 18630294..

Yang, L.-R., Chen, J.-H., and Wang, H.-W., (2012) Assessing Impacts of Information Technology on Project Success Through Knowledge Management Practice, Automation in Construction, Vol. 22, pp. 182-191. DOI: 10.1016/j.autcon.2011.06.016.

Zack, M. H., (1999) Knowledge and Strategy, Butterworth Heinemann: Boston, MA. 
Table 1 - Firm Status

\begin{tabular}{|c|c|c|c|c|c|}
\hline & Firms Status & Frequency & Percent & $\begin{array}{l}\text { Valid } \\
\text { Percent }\end{array}$ & $\begin{array}{l}\text { Cumulative } \\
\text { Percent }\end{array}$ \\
\hline \multirow[t]{4}{*}{ Valid } & $\begin{array}{l}\text { Enterprise/Sole } \\
\text { proprietorship }\end{array}$ & 27 & 28.7 & 28.7 & 28.7 \\
\hline & Private Limited Company & 54 & 57.4 & 57.4 & 86.2 \\
\hline & Partnership/Joint Venture & 13 & 13.8 & 13.8 & 100.0 \\
\hline & Total & 94 & 100.0 & 100.0 & \\
\hline
\end{tabular}


Table 2 - Years of Firm Existence

\begin{tabular}{|c|c|c|c|c|c|}
\hline Years of Existence & & Frequency & Percent & Valid Percent & $\begin{array}{l}\text { Cumulative } \\
\text { Percent }\end{array}$ \\
\hline \multirow[t]{5}{*}{ Valid } & Under 10 years & 31 & 33.0 & 33.0 & 33.0 \\
\hline & $10-20$ years & 14 & 14.9 & 14.9 & 47.9 \\
\hline & 21-30 years & 35 & 37.2 & 37.2 & 85.1 \\
\hline & Over 30 years & 14 & 14.9 & 14.9 & 100.0 \\
\hline & Total & 94 & 100.0 & 100.0 & \\
\hline
\end{tabular}


Table 3 - Experience of Professional

\begin{tabular}{lllllc}
\hline \multirow{2}{*}{ Years of Experience } & & Frequency & Percent & Valid Percent Percent \\
\hline Valid & Less than 5 years & 21 & 22.3 & 22.3 & 22.3 \\
& 5-10 years & 41 & 43.6 & 43.6 & 66.0 \\
& 11-15 years & 11 & 11.7 & 11.7 & 77.7 \\
& 16-20 years & 21 & 22.3 & 22.3 & 100.0 \\
\cline { 2 - 6 } & Total & $\mathbf{9 4}$ & $\mathbf{1 0 0 . 0}$ & $\mathbf{1 0 0 . 0}$ & \\
\hline
\end{tabular}


Table 4 - Descriptive Statistics of Knowledge Transfer in TT Projects

\begin{tabular}{lcclc}
\hline Knowledge Transfer Factors & $\mathbf{N}$ & Mean & $\begin{array}{l}\text { Standard } \\
\text { Deviation }\end{array}$ & $\begin{array}{l}\text { Standard } \\
\text { Error }\end{array}$ \\
\hline Knowledge Strategy & 94 & 4.01 & 0.711 & 0.073 \\
Organizational Culture & 94 & 3.95 & 0.556 & 0.057 \\
Information Technology & 94 & 4.26 & 0.604 & 0.062 \\
Knowledge Leadership & 94 & 4.00 & 0.703 & 0.073 \\
\end{tabular}


Table 5 - Spearman's Rank Correlation between Knowledge Transfer and Knowledge Enablers $(N=94)$

\begin{tabular}{lcccc}
\hline & $\begin{array}{l}\text { Knowledge } \\
\text { Strategy }\end{array}$ & $\begin{array}{l}\text { Organizational } \\
\text { Culture }\end{array}$ & $\begin{array}{l}\text { Information } \\
\text { Technology }\end{array}$ & $\begin{array}{l}\text { Knowledge } \\
\text { Leadership }\end{array}$ \\
\hline $\begin{array}{l}\text { Knowledge } \\
\text { Transfer }\end{array}$ & 0.618 & 0.691 & 0.702 & 0.721 \\
$(p=0.000)$ & $(p=0.000)$ & $(p=0.000)$ & $(p=0.000)$ \\
\hline
\end{tabular}

